\title{
On the Origin of Finnic *keühä 'poor'
}

The etymological dictionary of Finnish ${ }^{1}$ lists the following cognates for Finnic *keeühä 'poor': Fi. köyhä, Karelian keühä, Olonetsian keühü, Ludic köuh, köuh, keuh, Votic (Ahlqvist) cö̈̈hä, keühä (the latter form borrowed from Ingrian dialects), Estonian kehv, Gen. kehva. The Votic form čöühä, found only in the "Votisk Grammatik» by Ahlqvist, is dubious; one would expect * čeühä as the genuine Votic form. The general meaning of the Finnic words is 'pauper, inops'; the Estonian word also has meanings like 'gering, spärlich; schwach; unbefriedigend'. In the unpublished Veps lexical notes of E. N. Setälä there occurs kiouh, explained as 'paha, huono (ei = köyhä)' [= 'bad, inferior $($ not $=$ poor)].

From Finnic the word has been borrowed into many Lapp dialects: LpSw. kähe, köwe, L kiehē, kähhe $, k \bar{a} f \bar{e}, \mathrm{~N}$ gæfe, gefës, I kiehvi 'poor'. The possibility of the Lapp words being old cognates of the Finnic counterparts is ruled out by the soundcorrespondences.

Our word is thus limited to Finnic languages only. It does not occur in Livonian (which has joùtâm 'poor'). Veps koouh (Setälä) does not, to my knowledge, occur in other sources; it is, e.g., not listed in the new Veps dictionary recently published in the Soviet Union. ${ }^{2}$

It seems to be a common phenomenon that related languages do not possess old cognates denoting 'poor' or 'rich'. The suggestion has been put forth that in old primitive societies on the level of hunting and fishing there was no need for such words since it is probable that no marked differences in the

\footnotetext{
1 Y. H. Toivonen-Erkki Itkonen-Aulis J. Joki, Suomen kielen etymologinen sanakirja II (Lexica Societatis Fenno-Ugricae XII, 2, Helsinki 1958), p. 266.

${ }^{2}$ М. И. Зайцева - М. И. Муллонен, Словарь вепсского языка. Ленинград 1972.
} 
distribution of wealth existed in such societies. Presumably only in well developed agricultural societies did these distinctions begin to appear.

Words denoting 'poor', therefore, often seem to have received this meaning through secondary semantic development. Thus Latin pauper (pau-per, cf. pau-cus and pario) originally had the meaning 'wer sich wenig erworben hat'. The original sense of German arm 'poor' is assumed to have been 'vereinsamt, verlassen'. The semantic development may have been 'vereinsamt, verlassen' > 'beklagenswert, unglücklich' > 'pauper, inops'. Swedish fattig comes from old Sw. fä 'wenig' + töker 'was angenommen werden kann'. Livonian joùtôm 'poor' is a privative derivative from joùs 'Kraft, Stärke, Macht' and Russian бедный 'poor' is derived from беда 'Not'. Estonian has besides kehv also vaene (<vaivainen) from vaev $(<$ vaiva) 'trouble, pains, difficulty, toil', e.g. vaene kui kirikurott 'as poor as a church mouse'; in some Finnish dialects and in the old religious language vaivainen likewise has the meaning 'poor', e.g. Bible 1642 hengellisest waiwaiset 'poor in spirit, pauperes spiritu' (Matt. 5,3; in modern translation hengellisesti köyhät). The Czech word chudy' 'arm' (cf. also chudoba 'Armut', chudéti 'arm werden') has in other Slavic languages such cognates as Old Slavonic chudz 'klein, gering, dürftig, schlecht', Russ. худой 'schlecht, schlimm, mager'.

Words for 'poor' have also frequently been borrowed from other languages. English poor comes from Old French povre (< Latin pauper). Vogul nusa 'arm' is borrowed from Russ. нужа 'Armut'. ' Cheremis jorlo 'arm' is a Chuvash borrowing, cf. Chuvash jorlâ (Räsänen, MSFOu. 48, p. 137). Vog. jarlo 'arm, dürftig' is borrowed from the Tatar counterpart of the same word (Kannisto, FUF 17, p. 93). The Veps language has Russian loan words for 'poor': bedné (cf. Russ. бедный), gol, gol̄ (cf. Russ. голь 'беднота'), nužńe (cf. Russ. dial. нужный 'бедный'). Mordvin also has Russian borrowings: E бедной, М беднай 'бедный'.

The antonym of *keühä 'poor' in Finnic is Fi. rikas, Kar.

1 Béla Kálmán, Die russ. Lehnwörter im Wogulischen, p. 197-198. 
rikas, Votic rikaz, Est. rik̇as, Liv. rikàz 'rich'. The word is, as is well known, a borrowing from Germanic, cf. Swedish rik, German reich 'rich', Old Icelandic rīkr 'powerful', Gothic reiks 'ruler, noble, powerful', Old English rice 'strong, powerful, rich', Anglo-Saxon rice 'of high rank, powerful'.

Because of the origin of rikas it would not seem surprising if the origin of *keühä could also be traced to Germanic. Looking for a Germanic etymon that might be the source of the Finnic word we should try to find a word that would correspond phonetically to ${ }^{*} k e \ddot{u} h \ddot{a}$ and have a meaning from which the sense 'pauper, inops' could have been derived. I should like to suggest that Germanic *skeuhwa- is the word that would fill our requirements. There are no phonetic difficulties. It should be especially noted that in Germanic $w$ was regularly dropped from $h w$ in all Germanic languages except Gothic. ${ }^{*}$ skeuha- is represented by the following cognates in Germanic: Old English sīêoh 'timid', Middle English schey, shy 'shy (of a horse)', English shy 'schen, schüchtern', Old High German *scioh, Middle High German schiech 'schüchtern'. Swedish skygg derives from an etymologically related but phonetically different form.

Late Proto-Finnic *keühä corresponds exactly to Germanic *skeuha-: the initial cluster $s k$ - is represented by $k$ - as in Finnic kaunis 'beautiful' < Germanic *skauniz. As to the vowels, one might perhaps rather expect Finnic *keuha, but it should be noted that Germanic *beuda- (cf. Gothic biups, Old English bēod, Old Saxon biod, Old High German piot, beot 'table', Old Norse bjód 'Tisch, Schüssel') is borrowed into Finnic as *peütä (> Fi. pöytä 'table' etc.). Consequently, *keühä seems to be the perfectly normal rendering of Germanic *skeuha-.

As to the meaning of *keühä we could assume that the new word was borrowed in the sense of 'shy, timid'. Because the poor people were probably most often shy and timid, *keühä may have received the marginal meaning 'poor', with the marginal meaning eventually developing into the central one.

\footnotetext{
1 See, e.g., Hans Krahe, Germanische Sprachwissenschaft I (Sammlung Göschen), p. 83.
} 
We may add that if we accept the Germanic origin of *keühä it would not be the only Germanic adjective that has changed meaning in Finnic. A well known case is Finnic armas with the meaning of 'lieb, geliebt' which does not occur in Germanic. The original meaning of Germanic *armaz is assumed to have been 'vereinsamt, verlassen' and from this later 'beklagenswert, mitleidswert' $>$ 'poor'. In Finnic the meaning is assumed to have changed as follows: 'mitleidswert' $>$ 'der der Liebe bedarf' > 'lieb'. Another example is Finnish harras, G. hartaan 'fleissig, eifrig, andächtig, innig', cf. Gothic hardus 'hart, streng', Old Norse hardr 'hart', Old English heard 'hart, stark, tapfer', Old Saxon hard, Old High German hart 'hart, fest, schwer'.

Lauri Posti

P.S. After this article was set Mr. Reino Peltola informed me that the word kouh occurs in contemporay Northern Veps. Mr. Peltola has in his field notes kọ̈uh 'heikko, huono', kọ̈uhtuda keftuda 'huonontua, heiketä (esim. sairas)'.

L. P. 